\title{
THULIUM LASER VAPORIZATION VERSUS VAPOENUCLEATION (WITHOUT MORCELLATION) TECHNIQUE FOR BPH: DO WE HAVE A WINNER?
}

\author{
Debanga Sarma ${ }^{1}$, Yashasvi Singh ${ }^{1}$, Saumar Jyoti Baruah ${ }^{1}$, Rajeev T.P. ${ }^{1}$ Sasanka Kumar Barua ${ }^{1}$, Puskal \\ Kumar Bagchi ${ }^{1}$, Mandeep Phukan ${ }^{1}$, Manash Pratim Kashyap ${ }^{2}$ \\ 1Department of Urology, Gauhati Medical College Hospital, Guwahati, Assam, India \\ ${ }^{2}$ Assistant Professor, Department of Statistics, North Eastern Regional Institute of Management, Assam, India
}

Corresponding and Submitting author: Dr. Yashasvi Singh: Yashasvisingh075@gmail.com

Submitted: November 30, 2018. Accepted: January 23, 2019. Published: February 15, 2019.

\begin{abstract}
Background and Objective

The thulium laser surgery is a relatively new approach in which a wavelength of approximately $2 \mu \mathrm{m}$ is emitted in continuous-wave mode, thus enabling the precise incision of tissue by using a wavelength that matches the water absorption peak of $1.92 \mu \mathrm{m}$ in tissue. However, no published multinational study or other evidence definitively declares the superiority of thulium vaporization (ThuVAP) over thulium vapoenucleation (ThuVEP) without morcellator for better management of bothersome benign prostatic hyperplasia. The present study aims to evaluate the efficacy of vaporization and vapoenucleation (without a morcellator) in thulium laser prostatectomy for the treatment of benign prostatic hyperplasia.
\end{abstract}

\section{Methods}

A retrospective analysis of 82 patients who underwent thulium laser prostatectomy between February 2017 and January 2018 with ThuVAP and ThuVEP techniques was done and outcome measures analyzed were International Prostate Symptom Score (IPSS), quality-of-life score (QoL), maximum flow rate (Q max), post-void residual (PVRU), total operating time, laser time and resected tissue weight.

\section{Results}

No significant differences were noted between ThuVAP and ThuVEP in terms of post-operative prostate volume (22.4 vs. $21.7 \mathrm{~mL}$ ) and post-operative prostate specific antigen (PSA) (2.54 vs. $1.85 \mathrm{ng} / \mathrm{mL}$ ). Nonetheless, there were differences between the groups in total lasing time ( $56.5 \mathrm{vs} .44 .8 \mathrm{~min}, \mathrm{p}=0.001)$ and total operative time ( 88.5 vs. $71.5 \mathrm{~min}, \mathrm{p}=0.001$ ). There was also a significant difference in IPSS, QoL score, Q max, and PVRU at 6 weeks, 3 months, 6 months and 9 months after surgery. 


\section{Conclusion}

ThuVEP provides a superior reduction of prostate volume and better short-term clinical outcomes than ThuVAP in the treatment of patients with benign prostatic hyperplasia. Furthermore, ThuVEP results in significantly lower urethral discomfort rates with significant improvement in IPSS as compared to ThuVAP which is maintained over time. The hospital stay and catheter indwelling time are shorter in the ThuVEP group and the complications associated with it appear to be lower than ThuVAP group.

Key Words: thulium, vapoenucleation, vaporization, IPSS, laser

The past decade witnessed an advent of minimally invasive laser treatment for effective management of benign prostatic hyperplasia (BPH) and substitute transuretheral resection of the prostate by attaining a similar surgical outcome with decreasing morbidity. Despite the fact that traditional TURP is both effective and efficient, it is plagued with significant morbidities with $2-8 \%$ transfusion rate. ${ }^{1,2}$ Not very long ago, $\mathrm{Yu}$ and colleagues had analyzed practice patterns and stated that, traditional TURP accounted for $39 \%$ of surgical interventions for bothersome $\mathrm{BPH}$ while laser procedures accounted for a whopping $57 \% .^{3}$ The high-power thulium laser was first introduced in 2005 for the treatment of $\mathrm{BPH} .{ }^{4}$ Since then, the technique of thulium prostatectomy has gained significance with ThuVEP (Thulium laser vapoenucleation) showing encouraging clinical results using a similar technique comparable with holmium laser enucleation of the prostate (HoLEP). ${ }^{5}$ The wavelength of the thulium (2013 $\mathrm{nm})$ laser is very close to the peak for absorption in water $(1940 \mathrm{~nm})$, and this high-density energy is delivered in a continuous wave. The energy transforms to more efficient vaporization with shallower depth $(0.2 \mathrm{~mm})$ of penetration in tissue. ${ }^{6}$ which results in a smaller zone of thermal damage, which decreases post-operative dysuria that is commonly associated with transurethral laser prostate procedures. $^{7}$ The continuous wave mode is more suitable for hemostasis and coagulation of tissue, whereas the pulsed mode for is more suited for lithotripsy. ${ }^{8}$ The past researches using the $70-150 \mathrm{~W}$ thulium laser systems had demonstrated good short-term efficacy with low morbidity and few complications. This paper reviews the current evidence of safety and efficacy to evaluate the efficacy of vaporization, and vapoenucleation (without a morcellator) in thulium laser prostatectomy for the treatment of bothersome lower urinary tract symptoms due to BPH.

\section{METHODS}

In the present retrospective study, 82 patients with bothersome LUTS due to BPH who underwent thulium laser surgery [ThuVAP $(n=38)$ and ThuVEP $(n=44)$ ] between March 2017 and January 2018 were analyzed to evaluate the comparative efficacy and safety profile between the 2 given methods after obtaining institutional ethics committee clearance. Inclusion criteria consisted of age $\geq 50$ years, acute urinary retention with failed catheter free trial, symptomatic BPH with a maximal flow rate ( $Q$ max) of $<15 \mathrm{~mL} / \mathrm{s}$, and International Prostate Symptom Score (IPSS) $\geq 8$. Exclusion criteria were IPSS $\leq 7$, Q $\max \geq 15 \mathrm{~mL} / \mathrm{s}$, known case of adenocarcinoma, urodynamically confirmed neurogenic bladder and previous endoscopic surgery for BPH. Patients were thoroughly evaluated for all comorbidities preoperatively and at 6 weeks, and at 3,6 , and 9 months after surgery, using IPSS score, quality-of-life (QoL) score, Q max and post-void residual urine (PVRU). All intraoperative measures such as total operating time, laser-activation time, and estimated blood loss were noted for all the cases. The post-operative prostate volume was measured both pre-surgery and again at 3 months after the procedure to assess the vaporized prostate volume with the help of transrectal USG (TRUS). The operative time was calculated from insertion of the resectoscope into the urinary bladder to the perurethral catheterization at the end of the procedure. The lasing time was calculated when the laser was in use. Complications were graded according to the modified Clavien - Dindo-Dindo 
classification system. Because of inherent heterogeneous baseline characteristics among patients undergoing ThuVAP and ThuVEP, we used 1:1 propensity score matched analyses to adjust for these differences. A total of 64 patients who underwent ThuVAP $(n=32)$ or ThuVEP $(n=32)$ were analyzed. All the procedures were carried out by a single surgeon.

\section{SURGICAL METHODS}

Thulium laser prostatectomy was performed with the use of Quanta Cyber TM Thulium laser (Quanta System, Oloma, Italy). All patients were in lithotomy position and spinal or general anesthesia was achieved. We used a conventional $24 \mathrm{Fr}$ resectoscope in both the procedures. A $550 \mu \mathrm{m}$ end firing fiber was used to transmit laser energy to the prostate with an energy setting of $90 \mathrm{~W}$ for ThuVAP and $70 \mathrm{~W}$ for ThuVEP. For ThuVAP, we carried out the procedure with an "insideout" vaporization of the prostatic adenoma starting at verumontanum. The surgeon vaporized the adenoma arbitrarily which was not dependent on the exact surgical capsule between the adenoma and the peripheral zone. $^{9}$ (9). On the other hand, ThuVEP was carried out in an "outside in" vapoenucleation, as in holmium laser prostatectomy. ${ }^{10}(10)$. All the continuous pre and perioperative variables were analyzed using the independent $\mathrm{t}$-test. The categorical data were analyzed using the $\chi 2$-test. The correlation was established by using the Pearson's R coefficient. Propensity scores were obtained by multivariate logistic regression, based on age, prostate size and IPSS. All statistical analyses were carried out using SPSS software (version 21), and statistical significance was assumed at $\mathrm{p}<0.05$.

\section{RESULTS}

All baseline characteristics are listed in Table 1 and 1:1 propensity matched variables in Table 2 with their mean \pm SD values. None of the pre-operative variable had any significant differences between the two groups (Table 1 and 2). When considering both the groups for the intraoperative variables, it was found that when compared with ThuVEP, ThuVAP required longer operation time ( $88.5 \mathrm{vs}$. $71.5 \mathrm{~min}, \mathrm{p}=0.001)$, lasing time ( $56.5 \mathrm{vs} .44 .8$ minutes, $\mathrm{p}=0.001)$, energy used (305.1 kJ vs. $211.28 \mathrm{~kJ}, \mathrm{p}=.001)$ and post-operative serum PSA level $(2.54 \mathrm{ng} / \mathrm{mL}$ vs $1.85 \mathrm{ng} / \mathrm{mL}$ ). Four constant parameters such as IPSS,

FIG. 1 The Cyber TM 150 Watt thulium laser machine used in our study.

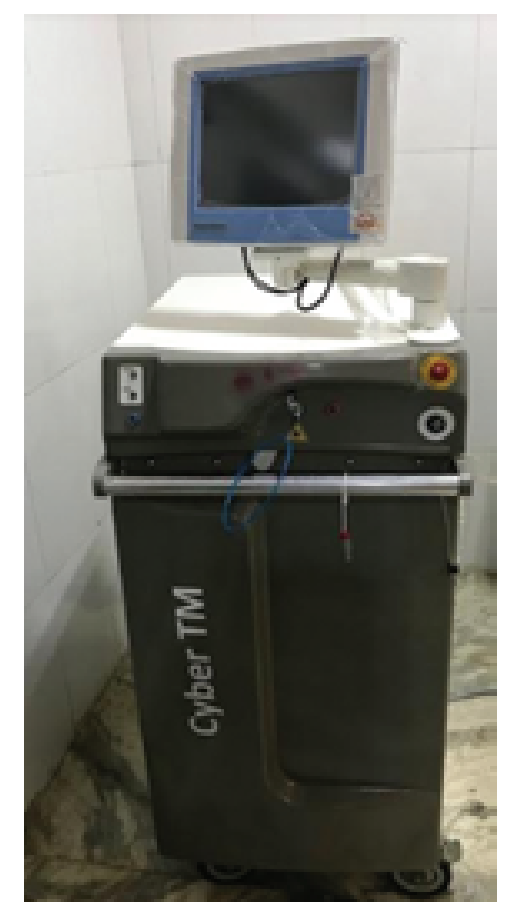

J Endolum Endourol Vol 2(1):e24-e36; February 15, 2019.

This article is distributed under the terms of the Creative Commons Attribution-Non

Commercial 4.0 International License. (C2019 Sarma et al. 
TABLE 1 Comparison of Baseline Characteristics in Overall Patient Group

\begin{tabular}{|c|c|c|c|c|}
\hline \multirow[b]{2}{*}{ Variable } & \multicolumn{4}{|c|}{ Complete Data Set } \\
\hline & ThuVAP & ThuVEP & $\begin{array}{l}\text { Independent } \\
\text { t-Test Variable }\end{array}$ & $p$ value \\
\hline No. patients & 38 & 44 & & \\
\hline Age (years) & $\begin{array}{c}59.12 \pm 6.45 \\
(52-66)\end{array}$ & $\begin{array}{c}60.10 \pm 4.82 \\
(55-67)\end{array}$ & 1.85 & .060 \\
\hline Pre-prostate size (cc) & $\begin{array}{c}83.45 \pm 13.56 \\
(74-154)\end{array}$ & $\begin{array}{c}94.15 \pm 17.22 \\
(84-161)\end{array}$ & .80 & .420 \\
\hline PSA $(n g / m L)$ & $\begin{array}{c}5.7 \pm 4.8 \\
(0.35-21)\end{array}$ & $\begin{array}{c}6.2 \pm 7.25 \\
(0.51-33)\end{array}$ & .35 & .926 \\
\hline Pre-operative IPSS & $\begin{array}{c}22.8 \pm 6.5 \\
(9-34)\end{array}$ & $\begin{array}{c}26.5 \pm 6.8 \\
(8-32)\end{array}$ & 1.48 & .085 \\
\hline Pre-operative QoL & $\begin{array}{c}4.2 \pm 1.1 \\
(1-6)\end{array}$ & $\begin{array}{c}3.1 \pm .88 \\
(1-6) \\
\end{array}$ & 1.77 & .071 \\
\hline $\begin{array}{l}\text { Pre-operative Q max } \\
(\mathrm{mL} / \mathrm{s})\end{array}$ & $\begin{array}{c}8.8 \pm 3.14 \\
(2.2-13.4) \\
\end{array}$ & $\begin{array}{c}9.2 \pm 2.65 \\
(1.7-15.6) \\
\end{array}$ & .70 & .642 \\
\hline Pre-operative PVRU (mL) & $\begin{array}{c}135 \pm 79.35 \\
(67-210)\end{array}$ & $\begin{array}{c}162 \pm 65.34 \\
(28-284)\end{array}$ & 1.28 & .122 \\
\hline
\end{tabular}

IPSS = International Prostate Symptom Score; PSA = prostate specific antigen; $P V R U=$ post-void residual; $Q O L=q u a l i t y$-of-life; ThuVAP = thulium vaporization; ThuVEP = thulium vapoenucleation.

TABLE 2 Comparison of Baseline Characteristics in Post Propensity Score Matched Patients

\begin{tabular}{|c|c|c|c|c|c|c|}
\hline \multirow[b]{2}{*}{ Variable } & \multicolumn{6}{|c|}{ Propensity matched data set } \\
\hline & ThuVAP & ThuVEP & $\begin{array}{c}\text { Independent } \\
\text { t-Test Variable }\end{array}$ & p value & Pearson's R & p value \\
\hline No. patients & 32 & 32 & & & & \\
\hline Age (years) & $\begin{array}{c}55.32 \pm 4.88 \\
(50-64)\end{array}$ & $\begin{array}{c}56.31 \pm 3.76 \\
(51-66)\end{array}$ & 1.90 & .006 & .122 & .532 \\
\hline Prostate size (cc) & $\begin{array}{l}92.45 \pm 12.56 \\
\quad(69-150)\end{array}$ & $\begin{array}{l}94.35 \pm 17.22 \\
\quad(72-152)\end{array}$ & 1.96 & .053 & .104 & .570 \\
\hline PSA (ng/mL) & $\begin{array}{c}4.7 \pm 2.8 \\
(0.70-13)\end{array}$ & $\begin{array}{l}4.9 \pm 3.10 \\
(.82-14) \\
\end{array}$ & .460 & .64 & .280 & .120 \\
\hline Pre-operative IPSS & $\begin{array}{c}19.8 \pm 4.5 \\
(9-33)\end{array}$ & $\begin{array}{c}21.5 \pm 4.8 \\
(9-33)\end{array}$ & .530 & .48 & .132 & .648 \\
\hline Pre-operative QoL & $\begin{array}{l}4.1 \pm .9 \\
(1-6)\end{array}$ & $\begin{array}{c}3.6 \pm 1.1 \\
(1-6)\end{array}$ & 2.03 & .082 & .150 & .722 \\
\hline $\begin{array}{l}\text { Pre-operative Q } \\
\max (\mathrm{mL} / \mathrm{s})\end{array}$ & $\begin{array}{l}7.9 \pm 3.14 \\
(1.8-12.4)\end{array}$ & $\begin{array}{l}8.6 \pm 2.65 \\
(1.7-13.6)\end{array}$ & 2.35 & .126 & .032 & .613 \\
\hline $\begin{array}{l}\text { Pre-operative } \\
\text { PVRU (mL) }\end{array}$ & $\begin{array}{c}142 \pm 59.85 \\
(60-190)\end{array}$ & $\begin{array}{c}159 \pm 62.14 \\
(17-259)\end{array}$ & .705 & .175 & .038 & .834 \\
\hline
\end{tabular}

IPSS = International Prostate Symptom Score; PSA = prostate specific antigen; $P V R U=$ post-void residual; $Q O L=$ quality-of-life; ThuVAP = thulium vaporization; ThuVEP = thulium vapoenucleation. 
TABLE 3 Perioperative and Post-operative Post Propensity Score Matched Patients Data According to Surgical Methods

\begin{tabular}{|c|c|c|c|c|c|c|}
\hline Variable & $\begin{array}{l}\text { ThuVAP } \\
(\mathrm{n}=32)\end{array}$ & $\begin{array}{l}\text { ThuVEP } \\
(n=32)\end{array}$ & $\begin{array}{c}\text { Independent } \\
\text { t-Test } \\
\text { Variable }\end{array}$ & p value & $\begin{array}{c}\text { Pearson's R } \\
\text { coefficient }\end{array}$ & $p$ value \\
\hline Total OT time (min) & $\begin{array}{c}88.5 \pm 24.18 \\
(46-132)\end{array}$ & $\begin{array}{c}71.5 \pm 22.87 \\
(37-108)\end{array}$ & 15.13 & .001 & .444 & .01 \\
\hline Laser time (min) & $\begin{array}{l}56.5 \pm 11.86 \\
(22-81)\end{array}$ & $\begin{array}{l}44.8 \pm 14.12 \\
\quad(17-66)\end{array}$ & 12.98 & .001 & .536 & .001 \\
\hline Energy used (kJ & $305.1 \pm 64.32$ & $211.28 \pm 48.32$ & 76.65 & .001 & .487 & .005 \\
\hline $\begin{array}{l}\text { Post op. PSA } \\
\mathrm{ng} / \mathrm{mL}\end{array}$ & $\begin{array}{c}2.54 \pm 2.6 \\
(.8-7.5)\end{array}$ & $\begin{array}{l}1.85 \pm 1.8 \\
(.5-14.2)\end{array}$ & 1.8 & .06 & .113 & .53 \\
\hline $\begin{array}{l}\text { Post op. Prostate size } \\
(\mathrm{cc} 3)\end{array}$ & $\begin{array}{c}22.4 \pm 12.57 \\
(13-52)\end{array}$ & $\begin{array}{c}21.7 \pm 10.05 \\
(11-74)\end{array}$ & .83 & .40 & .104 & .571 \\
\hline Vaporized volume (cc3) & $\begin{array}{c}59.05 \pm 21.38 \\
(21-78)\end{array}$ & $\begin{array}{c}73.65 \pm 17.61 \\
(15-96)\end{array}$ & 13.23 & .001 & .450 & .009 \\
\hline $\begin{array}{l}\text { Prostate volume } \\
\text { reduction } 3 \text { months (\%) }\end{array}$ & $\begin{array}{c}72.49 \pm 25.12 \\
(31-84)\end{array}$ & $\begin{array}{c}78.06 \pm 22.66 \\
(45-92)\end{array}$ & 4.55 & .001 & .262 & .140 \\
\hline $\begin{array}{l}\text { PSA reduction ( } 3 \\
\text { months) }(\%)\end{array}$ & $\begin{array}{c}46.80 \pm 17.8 \\
(19.32-62.1)\end{array}$ & $\begin{array}{c}62.24 \pm 27 \\
(29-77.23)\end{array}$ & 12.9 & .001 & .228 & .209 \\
\hline Catheterization time & $\begin{array}{c}3.3 \pm 0.6 \\
(1.8-5.4)\end{array}$ & $\begin{array}{c}2.5 \pm 1.1 \\
(1.2-4.8)\end{array}$ & 3.4 & .001 & .368 & .038 \\
\hline Mean hospital stay & $\begin{array}{c}4.5 \pm .8 \\
(2.9-7.5)\end{array}$ & $\begin{array}{c}3.6 \pm 1.3 \\
(2.2-5.4)\end{array}$ & 3.51 & .007 & .510 & .002 \\
\hline
\end{tabular}

PSA = prostate specific antigen; ThuVAP = thulium vaporization; ThuVEP = thulium vapoenucleation.

QoL, Q max, and PVRU were constantly monitored at 6 weeks, 3 months, 6 months, and 9 months. The IPSS score was significantly different between the 2 groups at 6 weeks and maintained at 6 months and 9 months (Table 4, Figure 2). The drop in IPSS from the pre-operative period to 9 months was $56.86 \%$ for the ThuVAP group and $71.16 \%$ for the ThuVEP group and was significantly different between the 2 groups $(\mathrm{p}=.012)$.

The QoL parameter was similarly analyzed at similar follow-up periods as mentioned earlier with significant difference observed at 6 weeks, 3 months and maintained at 9 months (Table 4, Figure 3). The increase in QoL from the pre-operative period to 9 months was $28.05 \%$ for the ThuVAP group and $40.28 \%$ for the ThuVEP group and was significantly different between the 2 groups ( $\mathrm{p}=.032$ ). The $\mathrm{Q}$ max was assessed and a significant difference was observed at
6 weeks, 3 months and maintained at 9 months (Table 4 , Figure 3, Figure 4). The increase in Q max from the pre-operative period to 9 months was a staggering $94.23 \%$ for the ThuVAP group and $102.28 \%$ for the ThuVEP group ( $\mathrm{p}=.150)$. Finally, PVRU was assessed at similar time periods and a significant difference was observed at 6 weeks and 3 months (Table 4, Figure 5). The decrease in PVRU from the pre-operative period to 9 months was $73.94 \%$ for the ThuVAP group and $78 \%$ for the ThuVEP group ( $\mathrm{p}=.350$ ). Most patients in each group were catheterized for 2 or 3 days, and if placed, the catheter was removed on the third postoperative day. When the per urethral catheter (PUC) time was analyzed, it was found that that the mean time for ThuVAP group was 3.3 days while it was 2.5 days for the ThuVEP group ( $\mathrm{p}=.001)$. Similarly the mean hospital stay was 4.5 days in the ThuVAP and 3.6 days in the ThuVEP group ( $\mathrm{p}=.007)$. 
TABLE 4 Follow-Up Functional Outcome; IPSS score, QoL, Q Max, PVRU at Showed Time Periods

\begin{tabular}{|c|c|c|c|c|c|c|c|}
\hline \multirow[b]{2}{*}{ Variable } & \multirow{2}{*}{$\begin{array}{c}\text { Follow-up } \\
\text { time }\end{array}$} & $\begin{array}{c}\text { ThuVAP } \\
(\mathrm{n}=32)\end{array}$ & $\begin{array}{c}\text { ThuVEP } \\
(\mathrm{n}=32)\end{array}$ & \multirow{2}{*}{$\begin{array}{c}\text { Independent } \\
\text { t-Test Variable }\end{array}$} & \multirow[b]{2}{*}{$p$ value } & \multirow[b]{2}{*}{ Pearson's R } & \multirow[b]{2}{*}{ p value } \\
\hline & & Mean \pm SD & Mean \pm SD & & & & \\
\hline \multirow[t]{4}{*}{ IPSS } & 6 weeks & $12.35 \pm 4.9$ & $8.75 \pm 5.7$ & 6.25 & .001 & .762 & .001 \\
\hline & 3 months & $10.22 \pm 3.8$ & $7.30 \pm 3.21$ & 1.96 & .052 & .184 & .313 \\
\hline & 6 months & $8.10 \pm 2.95$ & $5.25 \pm 2.18$ & 7.11 & .001 & .515 & .002 \\
\hline & 9 months & $8.54 \pm 2.80$ & $5.20 \pm 2.05$ & 6.01 & .001 & .662 & .001 \\
\hline \multirow[t]{4}{*}{ QoL } & 6 weeks & $4.12 \pm 2.82$ & $3.10 \pm 2.4$ & 2.51 & .013 & .401 & .02 \\
\hline & 3 months & $3.45 \pm 2.37$ & $2.45 \pm 1.2$ & 2.99 & .003 & .445 & .01 \\
\hline & 6 months & $3.12 \pm 1.98$ & $1.60 \pm 1.5$ & 1.88 & .063 & .142 & .438 \\
\hline & 9 months & $2.95 \pm 1.80$ & $1.15 \pm 1.1$ & 2.51 & .014 & .122 & .505 \\
\hline \multirow[t]{4}{*}{$\mathrm{Q} \max (\mathrm{mL} / \mathrm{s})$} & 6 weeks & $8.85 \pm 5.18$ & $12.43 \pm 4.5$ & 6.50 & .001 & .482 & .005 \\
\hline & 3 months & $14.75 \pm 3.11$ & $16.39 \pm 3.95$ & 3.49 & .007 & .675 & .001 \\
\hline & 6 months & $14.20 \pm 3.8$ & $17.15 \pm 3.12$ & 1.54 & .125 & .015 & .935 \\
\hline & 12 months & $15.15 \pm 3.5$ & $17.80 \pm 2.82$ & 5.96 & .001 & .105 & .567 \\
\hline \multirow[t]{4}{*}{ PVRU (mL) } & 6 weeks & $123 \pm 58$ & $110 \pm 42$ & 7.35 & .001 & .140 & .001 \\
\hline & 3 months & $78 \pm 28$ & $63 \pm 19$ & 12.37 & .001 & .672 & .001 \\
\hline & 6 months & $53 \pm 32$ & $51 \pm 24$ & 1.51 & .13 & .108 & .550 \\
\hline & 12 months & $37 \pm 24.5$ & $35 \pm 18.5$ & 1.72 & .08 & .102 & .578 \\
\hline
\end{tabular}

IPSS = International Prostate Symptom Score; PSA = prostate specific antigen; $P V R U=$ post-void residual; $Q O L=q u a l i t y$-of-life; ThuVAP = thulium vaporization; ThuVEP = thulium vapoenucleation.

FIG. 2 Showing mean IPSS variation with different follow-up periods $(*-p<.05)$.

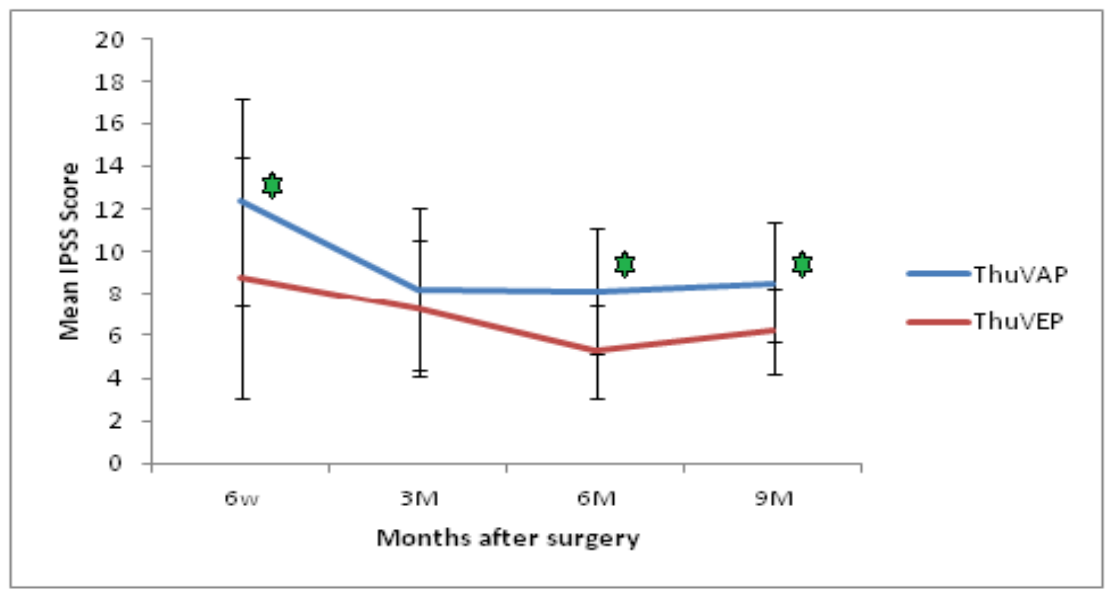

IPSS = International Prostate Symptom Score; ThuVAP = thulium vaporization; ThuVEP = thulium vapoenucleation. 
FIG. 3 Showing mean Q max variation with different follow-up periods $(*-p<.05)$.

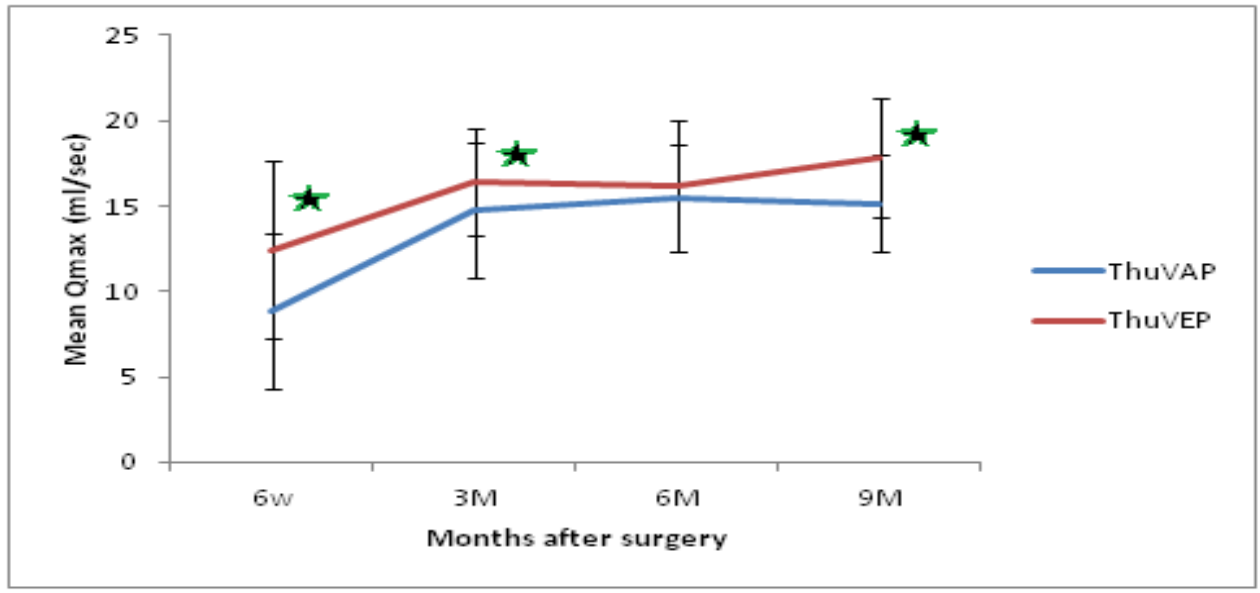

ThuVAP = thulium vaporization; ThuVEP = thulium vapoenucleation.

FIG. 4 Showing mean QoL variation with different follow-up periods $(*-\mathrm{p}<.05)$.

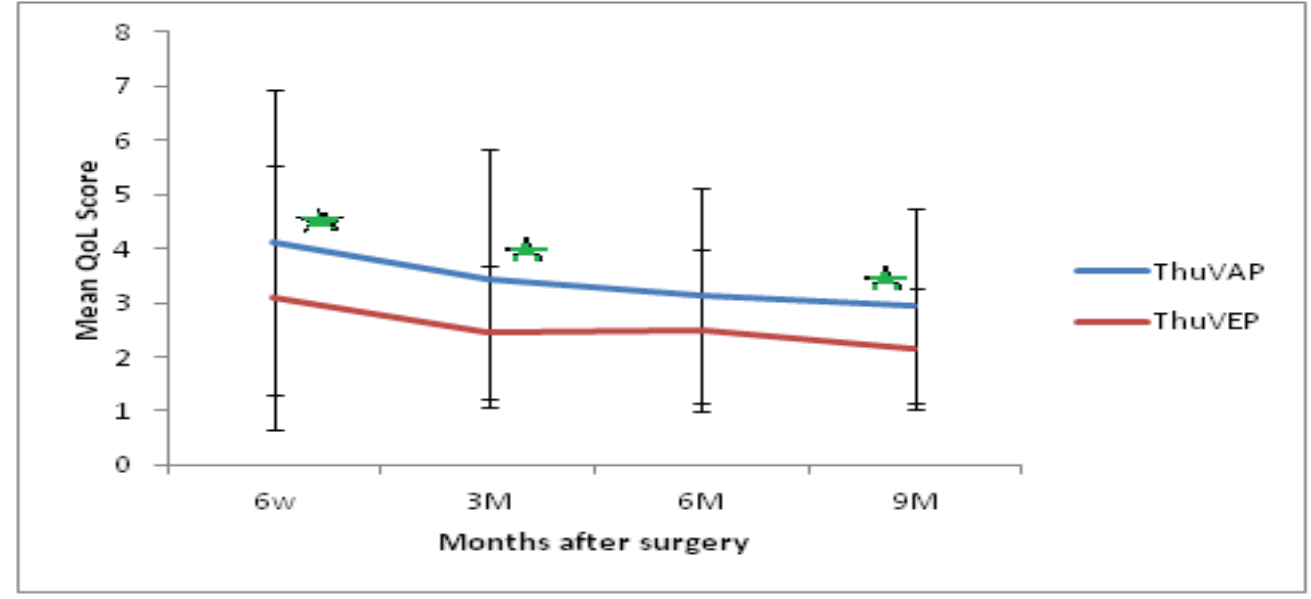

QoL $=$ Quality-of-Life; ThuVAP = thulium vaporization; ThuVEP = thulium vapoenucleation.

The Table 5 lists the complication according to the modified Clavien - Dindo classification system. The majority of the patients went through grade I-II complication (57.8\%). According to the 2004 Clavien - Dindo classification system, there were $22(34.38 \%)$ cases with grade I complications consisting of clot retention, transient incontinence, and bladder mucosal injury. Only one patient in the ThuVEP group required a blood transfusion. Within the 6 weeks after surgery, a significant difference in urethral discomfort (dysuria) was noted, with 14 patients (43.75\%) complaining of dysuria in the ThuVAP group versus 4 patients $(12.5 \%)$ in the ThuVEP group. Most of the dysuria was of persisting nature and remained bothersome till 6 months $(28.13 \%, n=9)$ post-surgery in the ThuVAP group. Delayed bleeding was observed in 3 of 32 patients $(9.38 \%)$ in the ThuVAP group, and none in the ThuVEP group and these patients required transurethral coagulation under general anesthesia. In the ThuVAP group, there were 2 patients with urethral strictures and bladder neck stenosis, resulting in voiding difficulty at 6 months after surgery, and these 
FIG. 5 Showing mean PVRU variation with different follow-up periods $(*-p<.05)$.

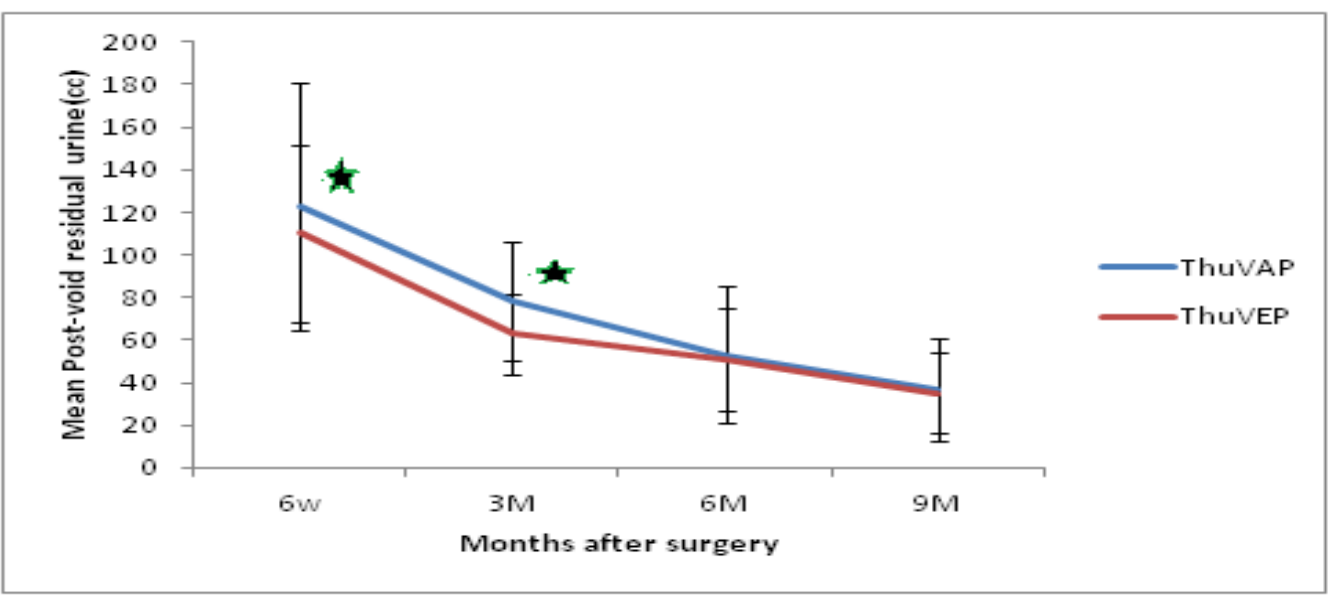

$P V R U=$ post-void residual; ThuVAP = thulium vaporization; ThuVEP = thulium vapoenucleation.

TABLE 5. Perioperative or Post-operative Complications in Post Propensity Matched Patients According to Modified Clavien - Dindo System

\begin{tabular}{|c|c|c|c|c|}
\hline \multicolumn{2}{|c|}{ Modified Clavien - Dindo system } & $\begin{array}{l}\text { ThuVAP } \\
(\mathrm{n}=32)\end{array}$ & $\begin{array}{l}\text { ThuVEP } \\
(n=32)\end{array}$ & p value \\
\hline \multirow[t]{5}{*}{ Grade 1} & Clot retention & $3(9.34)$ & $4(12.5)$ & .120 \\
\hline & $\begin{array}{l}\text { Hematuria } \\
\text { (Transient) }\end{array}$ & $12(37.5)$ & $7(21.88)$ & .336 \\
\hline & Urethral injury & $1(3.13)$ & 0 & .190 \\
\hline & Bladder mucosal injury & 0 & $1(3.13)$ & .324 \\
\hline & Transient SUI & $1(3.13)$ & $4(12.5)$ & .012 \\
\hline \multirow[t]{3}{*}{ Grade 2} & Hematuria & $2(6.25)$ & $3(9.34)$ & .540 \\
\hline & UTI & $4(12.5)$ & $1(3.13)$ & .203 \\
\hline & $\begin{array}{l}\text { Urethral } \\
\text { discomfort }\end{array}$ & $14(43.75)$ & $4(12.5)$ & .001 \\
\hline \multirow[t]{3}{*}{$\begin{array}{l}\text { Grade } \\
3 \mathrm{a}\end{array}$} & PUC block & $5(15.63)$ & $2(6.25)$ & .112 \\
\hline & $\begin{array}{l}\text { Extraperitoneal fluid } \\
\text { collection }\end{array}$ & 0 & 1(3.13) & .283 \\
\hline & Hemorrhage clot retention & $3(9.34)$ & 0 & .120 \\
\hline Grade $4 \mathrm{a}$ & Dialysis & $1(3.13)$ & $1(3.13)$ & .635 \\
\hline Grade $4 \mathrm{~b}$ & MODS & $1(3.13)$ & 0 & .200 \\
\hline Grade 5 & Death & 0 & 0 & .304 \\
\hline \multirow{3}{*}{$\begin{array}{l}\text { Long term } \\
\text { complication }\end{array}$} & Stricture & $1(3.13)$ & 0 & .132 \\
\hline & Bladder neck stenosis & $1(3.13)$ & 0 & .698 \\
\hline & Delayed hematuria & $7(21.88)$ & $2(6.25)$ & .286 \\
\hline
\end{tabular}

MODS = multiple organ dysfunction syndrome; $P C U=$ prostate cancer units; SIU = stress urinary incontinence; ThuVAP = thulium vaporization; ThuVEP = thulium vapoenucleation UTI = urinary tract infection. 
patients required optical internal urethrotomy bladder neck incision. All 3 patients of grade 4 complications recovered after a brief stay in ICU with intense monitoring and hemodialysis.

\section{DISCUSSION}

The existing laser platforms can be successfully used in various BPH surgery techniques. The scrutiny of their physical properties (target chromophore, wavelength, power and emitting mode) has enabled us to understand their mode of action such as vaporization, vaporesection, vapoenucleation and enucleation on prostatic adenomatous tissue and their possible clinical application. The thulium laser has efficient and even cutting combined with thorough hemostasis which is required for surgical safety in an unmatched manner. ${ }^{11,12}$ (11) (12). Since the properties of water remain static until water attains boiling point, the effect of the thulium laser remains constant throughout the surgery. ${ }^{13}$ (13). In the present analysis, the mean IPSS had improved threefold and fourfold in ThuVAP and ThuVEP group respectively post-surgery at 9 months. Similarly, the QoL parameter improved nearly 1.5 times in both the groups after surgery. In addition, the Q max had increased approximately twofold, and the PVRU volume had decreased by nearly $75 \%$ in both groups compared with the baseline values. It was observed that there was an immediate improvement in IPSS at 6 weeks after surgery which was maintained at 9 months and there was a significant difference between the two groups. This might be attributed to the higher post-operative irritative symptoms and urethral discomfort caused by the longer lasing time of the prostate adenoma in the ThuVAP group. Our analysis suggested that the number of patients who complained of urethral discomfort increased disproportionately in the ThuVAP group when compared to the ThuVEP group. It was hypothesized that in vaporization, the adenoma becomes rugged leading to application of high laser energy to the surface of the irregular adenoma to smoothen it for a longer period of time. This might be a possible aggravator for increased irritative symptoms and urethral discomfort immediately after surgery. In addition, an inside-out approach to vaporization might have led to the longer lasing time in travelling to the correct plane. In the present analysis it was proved beyond any shadow that ThuVAP required longer operation and laser times compared with ThuVEP. ThuVEP showed a significantly higher vaporization potential and prostate volume reduction rate after surgery (see Table 3). There was a meaningful difference of lasing time (56.5 minutes vs. 44.8 minutes) between the two groups which might have been the sole cause of increased irritative symptoms and urethral discomfort. We could remove more prostatic adenoma with the shorter surgical time in the ThuVEP group.

When the post-operative parameters were analyzed between the 2 groups (ThuVAP vs. ThuVEP), it was seen that the vaporized volume (59.05 gm vs. 73.65 $\mathrm{gm}, \mathrm{p}=.001)$, prostate volume reduction $(78.06 \% \mathrm{vs}$. $72.49 \%, \mathrm{p}=.001)$, and PSA reduction $(62.24 \% \mathrm{vs}$. $46.80 \%, \mathrm{p}=.001)$ were significantly different between the two groups (see Table 3). Bach et al. reported a mean prostate volume reduction of $86 \%$ and a PSA reduction of $88 \%$ after thulium laser vapoenucleation using a $120 \mathrm{~W}$ Tm:YAG laser with a routine power output of 90 Watt. ${ }^{14}$ (14). The present analysis failed to reach those reported percentages of prostate volume reduction and PSA decrease. Nevertheless, The present study was compared to the previous available literature in terms of efficacy and safety profile with 2 different arms compared with different observational studies as no past study has solely compared thulium vaporization with vapoenucleation (Table 6).

The thulium laser surgery for BPH had complication rates comparable with those published in large series on HoLEP and PVP but lower than TURP. ${ }^{15-17}$ The ThuVAP group had 3 cases of acute urinary retention (AUR) post PUC removal while the ThuVEP had 4 such cases. All these cases were recatheterized again and PUC removed after 48 to 72 hours after monitoring clinical progress. Reich and team 20 specified a rate of AUR of $5.8 \%$ for TURP and bleeding necessitating transfusion of $2.9 \% .{ }^{18}(18)$. In our series, $40.63 \%$ $($ ThuVAP $=12$, ThuVEP $=2$ ) of the patients remained on anticholinergic treatment, complaining of irritative LUTS 9 months after procedure. We adjudge these irritative symptoms post ThuVAP to the higher energy used and longer urethral time but at the same time the possible role of the bladder in irritative LUTS in men must be considered and rules out. It is estimated

J Endolum Endourol Vol 2(1):e24-e36; February 15, 2019.

This article is distributed under the terms of the Creative Commons Attribution-Non

Commercial 4.0 International License. (2019 Sarma et al. 
TABLE 6. Thulium Non-comparative Observation Studies in Comparison to Present Study

\begin{tabular}{|c|c|c|c|c|c|c|c|}
\hline \multirow[b]{2}{*}{ Reference } & \multirow[b]{2}{*}{ Technique } & \multirow[b]{2}{*}{ Comment } & \multirow{2}{*}{$\begin{array}{l}\text { Mean prostate } \\
\text { size }(\mathrm{g})\end{array}$} & \multirow{2}{*}{$\begin{array}{c}\text { Operative } \\
\text { time }\end{array}$} & $\begin{array}{c}\mathrm{Q} \max \\
(\mathrm{mL} / \mathrm{sec})\end{array}$ & \multirow{2}{*}{$\begin{array}{l}\text { Follow-up } \\
\text { (months) }\end{array}$} & \multirow[b]{2}{*}{ Complications } \\
\hline & & & & & PVRU (mL) & & \\
\hline \multirow{2}{*}{$\begin{array}{l}\text { Gross et al. } \\
(2012) 24(24)\end{array}$} & \multirow{2}{*}{$\begin{array}{l}\text { ThuVEP } \\
(\mathrm{n}=1080)\end{array}$} & \multirow[t]{2}{*}{$\mathrm{N} / \mathrm{A}$} & \multirow[t]{2}{*}{51} & \multirow[t]{2}{*}{$56(40-80)$} & $8.9 \rightarrow 18.4$ & \multirow[t]{2}{*}{1} & \multirow{2}{*}{$\begin{array}{c}\text { UTI }(8.4 \%) \text {, } \\
\text { Transfusion } \\
\quad(1.7 \%)\end{array}$} \\
\hline & & & & & $120 \rightarrow 20$ & & \\
\hline $\begin{array}{l}\text { Mahmood } \\
\text { Vazirian- } \\
\text { Zadeh et al. } \\
(2018) 16(16)\end{array}$ & $\begin{array}{l}\text { ThuLEP } \\
(n=222)\end{array}$ & $\begin{array}{c}\text { Mean PSA } \\
\text { reduction } \\
\text { post op } \\
70.50 \%\end{array}$ & 81 & N/A & $\begin{array}{c}159 \% \\
\text { improvement } \\
\text { in Q max } \\
61 \% \\
\text { improvement } \\
\text { in PVRU }\end{array}$ & N/A & $\begin{array}{l}.45 \% \text { patients } \\
\text { required blood } \\
\text { transfusion }\end{array}$ \\
\hline $\begin{array}{l}\text { Netsch et al. } \\
(2013) 25(25)\end{array}$ & $\begin{array}{l}\text { ThuVEP } \\
(n=56)\end{array}$ & $\begin{array}{c}\text { PSA } \\
\text { reduction } \\
87.6 \% \text { / } \\
\text { Prostate } \\
\text { volume } \\
\text { reduction } \\
75.9 \%\end{array}$ & 50 & $\begin{array}{c}61.5 \\
(40-100.75)\end{array}$ & N/A & 24 & $\begin{array}{c}\text { Transfusion } \\
(7.1 \%), \text { UTI } \\
(3.1 \%)\end{array}$ \\
\hline \multirow{2}{*}{$\begin{array}{l}\text { Sarma et al. } \\
(2018)^{\star}\end{array}$} & \multirow[t]{2}{*}{$\begin{array}{l}\text { ThuVEP } \\
(\mathrm{n}=32)\end{array}$} & \multirow{2}{*}{$\begin{array}{c}\text { PSA } \\
\text { reduction } \\
(62.24 \%), \\
\text { Prostate } \\
\text { volume } \\
\text { reduction } \\
(78.06 \%)\end{array}$} & \multirow[t]{2}{*}{$92.45 \pm 12.56$} & \multirow{2}{*}{$\begin{array}{c}56.5 \pm 11.86 \\
\text { (lasing } \\
\text { time) }\end{array}$} & $8.8 \rightarrow 17.8$ & \multirow[t]{2}{*}{9} & \multirow{2}{*}{$\begin{array}{c}\text { Urethral } \\
\text { discomfort } \\
(12.5 \%), \text { UTI } \\
(3.13 \%)\end{array}$} \\
\hline & & & & & $159 \rightarrow 35$ & & \\
\hline $\begin{array}{l}\text { Pariser et al. } \\
(2014) 18 \text { (18) }\end{array}$ & $\begin{array}{l}\text { ThuVAP } \\
(\mathrm{n}=59)\end{array}$ & N/A & $57 \pm 30.2$ & $\begin{array}{c}35 \pm 18 \text { (laser } \\
\text { time) }\end{array}$ & N/A & 3 & UTI (10\%) \\
\hline $\begin{array}{l}\text { Vargas et al. } \\
(2014) 27 \text { (27) }\end{array}$ & $\begin{array}{l}\text { ThuVAP } \\
(\mathrm{n}=55)\end{array}$ & $\begin{array}{l}\text { IPSS was } \\
\text { reduced } \\
\text { by } 16.88 \\
\text { points }\end{array}$ & $42.53 \pm 17.41$ & $51.62 \pm 19.76$ & $\begin{array}{l}\text { Q max was } \\
\text { Increased by } \\
9.33 \mathrm{~mL} / \mathrm{sec}\end{array}$ & 6 & UTI (3.6\%) \\
\hline \multirow[t]{2}{*}{$\begin{array}{l}\text { Sarma et al. } \\
(2018)^{*}\end{array}$} & \multirow[t]{2}{*}{$\begin{array}{l}\text { ThuVAP } \\
(\mathrm{n}=32)\end{array}$} & \multirow{2}{*}{$\begin{array}{c}\text { PSA } \\
\text { reduction } \\
(46.80 \%), \\
\text { Prostate } \\
\text { volume } \\
\text { reduction } \\
(72.49 \%)\end{array}$} & \multirow[t]{2}{*}{$94.35 \pm 17.22$} & \multirow{2}{*}{$\begin{array}{c}44.8 \pm 14.12 \\
\text { (lasing } \\
\text { time) }\end{array}$} & $7.8 \rightarrow 15.15$ & \multirow[t]{2}{*}{9} & \multirow{2}{*}{$\begin{array}{c}\text { Urethral } \\
\text { discomfort } \\
(43.75 \%), \text { UTI } \\
(12.5 \%)\end{array}$} \\
\hline & & & & & $142 \rightarrow 37$ & & \\
\hline
\end{tabular}

IPSS = International Prostate Symptom Score; $P S A=$ prostate specific antigen; $P V R U=$ post-void residual; ThuVAP = thulium vaporization; ThuVEP = thulium vapoenucleation. 
that approximately $35 \%$ of patients presenting with obstructive LUTS may report concomitant irritative symptoms. ${ }^{19}$ (19). In addition, up to $1 / 3$ of patients undergoing prostatectomy may present with urgency symptoms up to 11 months after surgery. ${ }^{20}(20)$. A recent study described the appearance of urge urinary incontinence not associated with detrusor hyperactivity in $50 \%$ of patients who underwent vaporization with 120 Watt LBO, which remitted in the subsequent 3 to 12 months..$^{25}(25)$.

The present analysis showed no statistically significant difference in any other complications except transient SUI and dysuria in both arms. There was a single bladder mucosal injury in the ThuVEP group developed in the process of vaporizing that enucleated portion of the prostate intravesically. Three patients required transurethral coagulation under general anesthesia because of hemorrhage or delayed bleeding. In the present analysis patients were requested to discontinue anticoagulant and antiplatelet therapies 5-7 days before surgery after taking cardiology consultation. The data of the patients who were still taking anticoagulants due to unavoidable cardiac circumstances were excluded from the propensity matching analysis. Stress urinary incontinence was found in $4(12.5 \%)$ patient in the ThuVEP group, and 1 (3.13\%) in the ThuVAP group with significant difference between them $(p=.012)$. Though this was a transient condition, this was attributable to the loss of hammock like support to the external urethral sphincter. The similar incidence of urinary incontinence, compared with HoLEP could be as a result of less injury to the external sphincter or a smaller portion of the prostate adenoma removed..$^{22,23}$ It was observed in our analysis that with the use of ThuVAP, the urethral discomfort rate did not decrease over time ( 3 to 6 months) irrespective of the surgeons' experience. The sexual function was preserved in both the groups (6 to 9 months) based on the IIEF -5 questionnaire confirming the fact that ThuLEP was mostly safe from the grievous complication of erectile dysfunction.

The present analysis was not without any limitations. First, ours was not a randomized prospective study and some selection bias might have crept in despite of best efforts in terms of complication recordings.
We tried to have telephonic conversation whenever the data was insufficient or misguiding. Second, there was a learning curve initially for the surgeon's surgical technique which got refined and tuned with time but these factors were not part of our analysis, making it impossible to evaluate their impact. Thirdly, the current follow-up period might not be long enough to draw parallel on long term post-operative efficiency between the 2 study arms and their and complications. Nonetheless, efficacy and feasibility could be demonstrated by the aforementioned results, further follow-up will be required to verify improvement in urinary symptoms and the need of redo surgery if any.

\section{CONCLUSION}

This is the first effort to our knowledge to evaluate the efficacy and safety of two different methods in thulium laser prostatectomy though retrospective in nature. Our key observations were that ThuVEP at $70 \mathrm{~W}$ has several advantages over ThuVAP at 90-Watt power. The lasing time was shorter with ThuVEP than with ThuVAP leading to better post-operative urethral comfort profile and lower IPSS in terms of irritative symptoms. The mean prostate volume reduction rate, mean vaporized volume, along with mean PSA drop percentage was significantly better with ThuVEP than with ThuVAP group. The hospital stay and catheter indwelling time are shorter in the ThuVEP group and the complications associated with it appear to be lower than ThuVAP group. The future of thulium laser surgery has just knocked on the endless opportunities of BPH management and there is a strong conviction that thulium would sooner or later replace TURP as the gold standard measure to deal with big prostate glands. Further RCTs with both arms of ThuVAP and ThuVEP will pave the way for validation of our results and new insights in surgical techniques.

\section{ACKNOWLEDGEMENTS}

None.

\section{CONFLICT OF INTEREST}

None declared.

\section{FUNDING}

None. 


\section{REFERENCES}

1. Rassweiler J, Teber D, Kuntz R, Hofmann R. Complications of transurethral resection of the prostate (TURP)-incidence, management, and prevention. Eur Urol 2006;50:969-79.

2. Mebust W, Holtgrewe H, Cockett A, Peters P. Transurethral prostatectomy: immediate and postoperative complications. A cooperative study of 13 participating institutions evaluating 3,885 patients. J Urol 1989;141:243-47.

3. Yu X, Elliott S, Wilt T, Mcbean A. Practice patterns in benign prostatic hyperplasia surgical therapy: the dramatic increase in minimally invasive technologies. J Urol 2008; 180:241-45.

4. Xia S, Zhuo J, Sun X, Han B, Shao Y, Zhang Y. Thulium laser versus standard transurethral resection of the prostate: a randomized prospective trial. Eur Urol 2008;53:383-90.

5. Szlauer R GRRAPLSN.. Endoscopic vaporesection of the prostate using the continuous-wave 2-microm thulium laser: outcome and demonstration of the surgical technique. Eur Urol 2009;55:368-75.

6. Fried N., Murray K. High-power thulium fiber laser ablation of urinary tissues at 1.94 microm. J Endourol 2005;19:25-31.

7. Reich O, Gratzke C, Bachmann A, et al. Morbidity mortality and early outcome of transurethral resection of the prostate: a prospective multicenter evaluation of 10,654 patients. J Urol 2008;180:246-49.

8. Hardy L, Wilson C, Irby P, Fried N. Thulium fiber laser lithotripsy in an in vitro ureter model. J Biomed Opt 2014; 19:128001.

9. Bach T, Wendt-Nordahl G, Michel MS, Herrmann TR, Gross AJ. Feasibility and efficacy of Thulium:YAG laser enucleation (VapoEnucleation) of the prostate. World J Urol 2009;27:541-5.

10. Shah HN, Sodha HS, Kharodawala SJ, Khandkar AA, Hegde SS, Bansal MB. Influence of prostate size on the outcome of holmium laser enucleation of the prostate. BJU Int 2008;101:1536-41.

11. Bouchier-Hayes DM, Van Appledorn S, Bugeja P. A randomized trial of photoselective vaporization of the prostate using the $80-\mathrm{W}$ potassium-titanyl-phosphate laser vs transurethral prostatectomy, with a 1-year follow-up. BJU Int 2009;105:964-69.

12. Lukacs B, Loeffler J, Bruye're F. Photoselective vaporization porization of the prostate with GreenLight
120-W laser compared with monopolar transurethral resection of the prostate: A multicencer randomized controlled trial. EurUrol 2012;61:1165-73.

13. Herrmann TW, Liatsikos E, Nagele U. EAU guidelines lines on laser technologies. Eur Urol 2012;61:783-95.

14. Bach T, Netsch C, Pohlmann L, Herrmann TR, Gross AJ. Thulium:YAG vapoenucleation in large volume prostates. J Urol 2011;186:2323-7.

15. Gross A, Netsch C, Knipper S., et al. Complications and early postoperative outcome in 1080 patients after thulium vapoenucleation of the prostate: results at a single institution. Eur Urol 2012;63:859-67.

16. Vazirian-Zadeh M, Anderson J, Gill R, et al. Thulium laser enucleation of the prostate (thulep) as a technique for treatment of BPH: Evaluation of a six-year experience at a single institution. J Endolum Endourol 2018 Oct;1(2):10-14.

17. Netsch C, Bach T, Herrmann T, et al. Evaluation of the learning curve for Thulium VapoEnucleation of the prostate (ThuVEP) using a mentor-based approach. World J Urol 2013;31:1231-38.

18. Pariser J, Famakinwa O, Pearce S, Chung D. High-power thulium laser vaporization of the prostate: short-term outcomes of safety and effectiveness. J Endourol 2014 Oct;28(8):1357-62.

19. Vargas C, Garcia-Larrosa A, Capdevila S,Laborda A. Vaporization of the prostate with $150-\mathrm{W}$ thulium laser: complications with 6-month follow-up. J Endourol 2014;28:841-45.

20. Shah HN, Mahajan AP, Hegde SS, Bansal MB. Perioperative complications of holmium laser enucleation of the prostate: experience in the first 280 patients, and a review of literature. BJU Int 2007;100:94-101.

21. Bachmann A, Muir GH, Collins EJ. 180-W XPS GreenLight laser therapy for benign prostate hyperplasia: early safety, efficacy, and perioperative outcome after 201 procedures. Eur Urol 2012;61:600-7.

22. Ruszat R, Wyler SF, Seitz M. Comparison of potassiumtitanylphosphate laser vaporization of the prostate and transurethral resection of the prostate: update of a prospective non-randomized two-centre study. BJU Int 2008;102:1432-8.

23. Reich O, Gratzke C, Bachmann A, Seitz M, SchlenkerB, Hermanek P. Morbidity, mortality and early outcome of transurethral resection of the prostate: a prospective multicenter evaluation of 10,654 patient. J Urol 2008;180:246-49. 
24. Coyne KS, Kaplan SA, Chapple CR. Risk factors and comorbid conditions associated with lower urinary tract symptoms: EpiLUTS. BJU Int 2009;103(3):24-32.

25. Neal DE, Ramsden PD, Sharples L. Outcome of elective prostatectomy. BMJ 1989;299:762-67.

26. Montorsi F, Naspro R, Salonia A. Holmium laser enucleation versus transurethral resection of the prostate: results from a 2-center prospective randomized trial in patients with obstructive benign prostatic hyperplasia. J Urol 2004;172:1926-9.

27. Ahyai SA, Gilling P, Kaplan SA. et al. Meta-analysis of functional outcomes and complications following transurethral procedures for lower urinary tract symptoms resulting from benign prostatic enlargement. Eur Urol 2010;58:384-97.

28. Zhang F, Shao Q, Herrmann TR, Tian Y, Zhang Y. Thulium laser versus holmium laser transurethral enucleation of the prostate: 18 -month follow-up data of a single center. Urology 2012;79:869-74.

29. Parsons J, Bergstrom J, Silberstein J, Barrett Connor E. Prevalence and characteristics of lower urinary tract symptoms in men aged $>$ or $=80$ years. Urology 2008;72:318-21. 